\title{
Cobalt oxide nanoparticles aggravate DNA damage and cell death in eggplant via mitochondrial swelling and NO signaling pathway
}

\author{
Mohammad Faisal ${ }^{1 *+}$ (D), Quaiser Saquib ${ }^{2,3+}{ }^{2}$, Abdulrahman A. Alatar ${ }^{1}$, Abdulaziz A. Al-Khedhairy ${ }^{2,3}$, \\ Mukhtar Ahmed ${ }^{3}$, Sabiha M. Ansari ${ }^{1}$, Hend A. Alwathnani ${ }^{1}$, Sourabh Dwivedi ${ }^{4}$, Javed Musarrat ${ }^{4,5}$ \\ and Shelly Praveen ${ }^{6}$
}

\begin{abstract}
Background: Despite manifold benefits of nanoparticles (NPs), less information on the risks of NPs to human health and environment has been studied. Cobalt oxide nanoparticles $\left(\mathrm{CO}_{3} \mathrm{O}_{4}-\mathrm{NPs}\right)$ have been reported to cause toxicity in several organisms. In this study, we have investigated the role of $\mathrm{CO}_{3} \mathrm{O}_{4}-\mathrm{NPS}$ in inducing phytotoxicity, cellular DNA damage and apoptosis in eggplant (Solanum melongena $\mathrm{L}$. cv. Violetta lunga 2). To the best of our knowledge, this is the first report on $\mathrm{CO}_{3} \mathrm{O}_{4}-\mathrm{NPS}$ showing phytotoxicity in eggplant.

Results: The data revealed that eggplant seeds treated with $\mathrm{CO}_{3} \mathrm{O}_{4}-\mathrm{NPs}$ for $2 \mathrm{~h}$ at a concentration of $1.0 \mathrm{mg} / \mathrm{ml}$ retarded root length by $81.5 \%$ upon 7 days incubation in a moist chamber. Ultrastructural analysis by transmission electron microscopy (TEM) demonstrated the uptake and translocation of $\mathrm{CO}_{3} \mathrm{O}_{4}$-NPs into the cytoplasm. Intracellular presence of $\mathrm{CO}_{3} \mathrm{O}_{4}$-NPs triggered subcellular changes such as degeneration of mitochondrial cristae, abundance of peroxisomes and excessive vacuolization. Flow cytometric analysis of $\mathrm{CO}_{3} \mathrm{O}_{4}-\mathrm{NPs}(1.0 \mathrm{mg} / \mathrm{ml})$ treated root protoplasts revealed 157, 282 and $178 \%$ increase in reactive oxygen species (ROS), membrane potential $(\Delta \psi m)$ and nitric oxide $(\mathrm{NO})$, respectively. Besides, the esterase activity in treated protoplasts was also found compromised. About 2.4-fold greater level of DNA damage, as compared to untreated control was observed in Comet assay, and $73.2 \%$ of $\mathrm{CO}_{3} \mathrm{O}_{4^{-}}$ NPs treated cells appeared apoptotic in flow cytometry based cell cycle analysis.

Conclusion: This study demonstrate the phytotoxic potential of $\mathrm{CO}_{3} \mathrm{O}_{4}-\mathrm{NPs}$ in terms of reduction in seed germination, root growth, greater level of DNA and mitochondrial damage, oxidative stress and cell death in eggplant. The data generated from this study will provide a strong background to draw attention on $\mathrm{CO}_{3} \mathrm{O}_{4}-\mathrm{NPs}$ environmental hazards to vegetable crops.
\end{abstract}

Keywords: Cobalt oxide nanoparticles, Nanotoxicity, DNA damage, Apoptosis, Oxidative stress

\section{Background}

Over a last decade, nanotechnology has gained an immense research interest due to its applications in public health, medicine, industry and agriculture. The

\footnotetext{
*Correspondence: faisalm15@yahoo.com

${ }^{\dagger}$ Mohammad Faisal and Quaiser Saquib contributed equally to this work

1 Department of Botany and Microbiology, College of Sciences, King Saud

University, P.O Box 2455, Riyadh 11451, Saudi Arabia

Full list of author information is available at the end of the article
}

incessant use of nanoparticles (NPs) in a multitude of sectors presents a risk of their release into the environment, which may pose serious threats on ecosystem and adversely affect its living entity [1]. Particularly, plants are at maximum risk due to the concentration build-up of NPs in natural sediments, agricultural soils, and aquatic environments $[1,2]$. Recent evidences on the NPs toxicity demonstrated the cellular uptake of Ag-NPs in Oryza Sativa and $\mathrm{Cu} / \mathrm{CuO}-\mathrm{NPs}$ in Lactuca sativa $[3,4]$. Vicia 
faba exposed to multiwalled carbon nano tubes exhibited imbalance of nutrient elements, leaves damage and oxidative stress [5]. The uptake and translocation of $\mathrm{TiO}_{2}-$ NPs in Allium cepa induces heavy ROS generation, sticky, multipolar and laggard chromosomes, including micronucleus formation and DNA damage [6]. These effects of NPs are primarily associated with their increased surface area and reactivity, ROS generation and the tendency to form agglomerates [4]. We have selected $\mathrm{Co}_{3} \mathrm{O}_{4}-\mathrm{NPs}$ for the current investigation due to its unique physical properties, applications in pigments, catalysis, sensors, electrochemistry, magnetism and energy storage [7]. In addition, the composites of $\mathrm{Co}_{3} \mathrm{O}_{4}$-NPs with multiwalled carbon nanotubes have been proposed for fabricating high-performance electronic devices [8].

Till date, only a solitary report on $\mathrm{Co}_{3} \mathrm{O}_{4}$-NPs demonstrated the reduction of root length in $A$. cepa, without much elaboration on the nature of cellular damage and mechanism of the phytotoxicity [9]. Therefore, in this study, we have investigated the mechanistic aspects of $\mathrm{Co}_{3} \mathrm{O}_{4}$-NPs toxicity in eggplant (Solanum melongena L. cv. Violetta lunga 2), an economically important vegetable crop, as a model, using state-of-the-art techniques like transmission electron microscopy (TEM), comet assay and flow cytometry. This will help in understanding as to how the plant responds to NPs exposure and regulates the molecular mechanism of cell death pathways. Since no systematic study has been attempted so far, describing the mechanism of $\mathrm{Co}_{3} \mathrm{O}_{4}$-NPs induced phytotoxicity in eggplant at cellular and molecular levels, we have investigated the effect of $\mathrm{Co}_{3} \mathrm{O}_{4}$-NPs on eggplant cells to assess the (1) phytotoxicity, (2) translocation of $\mathrm{Co}_{3} \mathrm{O}_{4}$-NPs in root cells and subcellular anomalies, (3) intracellular ROS generation and mitochondrial dysfunction $(\Delta \Psi m),(4)$ DNA damage (5) cell cycle alterations, NO generation and esterase activity.

\section{Results and discussion $\mathrm{Co}_{3} \mathrm{O}_{4}$-NPs characterization}

Size and morphology of $\mathrm{Co}_{3} \mathrm{O}_{4}$-NPs were examined by TEM and AFM analyses. TEM image in Fig. 1 revealed the morphology of $\mathrm{Co}_{3} \mathrm{O}_{4}$-NPs as crystallite spheres with polyhedral structure, and aggregates have been observed. The average particle size of $\mathrm{Co}_{3} \mathrm{O}_{4}$-NPs determined from six different TEM images were $21.3 \mathrm{~nm}$ (Fig. 1a). AFM analysis of $\mathrm{Co}_{3} \mathrm{O}_{4}$-NPs exhibited the size of NPs to be $40 \mathrm{~nm}$ (Fig. 1b). Since, the sizes of NPs are regarded as important parameters for cellular toxicity; the behavior of $\mathrm{Co}_{3} \mathrm{O}_{4}$-NPs in treatment solutions was examined through DLS, to understand the extent of aggregation and secondary size of NPs. The data revealed large particle aggregates of $359.7 \pm 2.1 \mathrm{~nm}$ with $\zeta$-potential of $-6.2 \pm 1.3 \mathrm{mv}$ (Fig. 1c, d). DLS is widely used to determine the size of Brownian NPs in colloidal suspensions in the nano and submicron ranges [10]. The average hydrodynamic particle's diameter in water indicates particle aggregation. Our characterization data corroborates well with the recent report on agglomeration of NPs in an aqueous environment [3].

$\mathrm{Co}_{3} \mathrm{O}_{4}$-NPs treatment retarded the root growth of eggplant $\mathrm{Co}_{3} \mathrm{O}_{4}$-NPs treated seeds exhibited a tendency to adsorb on the seed coat in a concentration dependent manner, while bulk $\mathrm{Co}_{3} \mathrm{O}_{4}$ did not display adsorption behavior on the seeds (Fig. 2a). These observations are in line with our previous report exhibiting the adsorption tendency NiO-NPs on the tomato seeds [11]. Such behavior could be due to the physical attachment of particles on a rough seed surface, electrostatic attraction and hydrophobic interactions between seeds and NP agglomerates. It is likely that the adsorption of NPs may facilitate the release of ions locally to enhance phytotoxic effects [11]. Exposure concentrations for $\mathrm{Co}_{3} \mathrm{O}_{4}$-NPs were selected based on the screening of low to high concentrations (0.025$1.0 \mathrm{mg} / \mathrm{ml}$ ) of $\mathrm{Co}_{3} \mathrm{O}_{4}$-NPs to affect the root length. Since, the primary objective of this study was to assess the toxicity of $\mathrm{Co}_{3} \mathrm{O}_{4}$-NPs. Therefore, the non-significant concentrations $(0.025-0.1 \mathrm{mg} / \mathrm{ml})$ in terms of repression of root lengths were excluded from further toxicity experiments. After 7 days of incubation, average root lengths recorded at 0.5 and $1.0 \mathrm{mg} / \mathrm{ml}$ of $\mathrm{Co}_{3} \mathrm{O}_{4}$ - $\mathrm{NPs}$ were $1.0 \pm 0.16$ and $0.70 \pm 0.18 \mathrm{~cm}(\mathrm{p}<0.01)$ respectively. The root length in untreated control was $3.80 \pm 0.24 \mathrm{~cm}$ (Fig. 2b). Under similar experimental conditions, bulk $\mathrm{Co}_{3} \mathrm{O}_{4}$ did not induce repression of root length (Fig. 2b). Phenotypic analysis of roots revealed that $\mathrm{Co}_{3} \mathrm{O}_{4}-\mathrm{NPs}(0.25,0.5$ and $1.0 \mathrm{mg} / \mathrm{ml}$ ) treated groups exhibited a dose-dependent reduction in root length along with thickening, stunted growth and absence of root hairs. However, no such changes have been observed in bulk $\mathrm{Co}_{3} \mathrm{O}_{4}$ treated groups (Fig. 2c). Due to the non-significant effects of bulk $\mathrm{Co}_{3} \mathrm{O}_{4}$ on eggplant root length, we have excluded bulk $\mathrm{Co}_{3} \mathrm{O}_{4}$ in further experiments. Comparison of data with our recently published studies on NiO-NPs induced toxicity in tomato, suggested that $\mathrm{Co}_{3} \mathrm{O}_{4}$-NPs are more growth inhibitory at the highest concentration of $1.0 \mathrm{mg} /$ $\mathrm{ml}$ and exhibited 2.14-fold greater repression of root length in eggplant. Thickening and stunted roots were observed at all treatment concentrations of $\mathrm{Co}_{3} \mathrm{O}_{4}-\mathrm{NPs}$ after 7 days, while the NiO-NPs treated tomato roots were found thickened and stunted only at greater concentrations of 1.5 and $2 \mathrm{mg} / \mathrm{ml}$ after 10 days of exposure [11], thus, suggesting the higher toxicity of $\mathrm{Co}_{3} \mathrm{O}_{4}$-NPs. The differences in toxicity of $\mathrm{Co}_{3} \mathrm{O}_{4}$-NPs over NiO-NPs can be attributed to the difference in seed size of the two plants. Indeed, the interactions of similar-sized NPs 

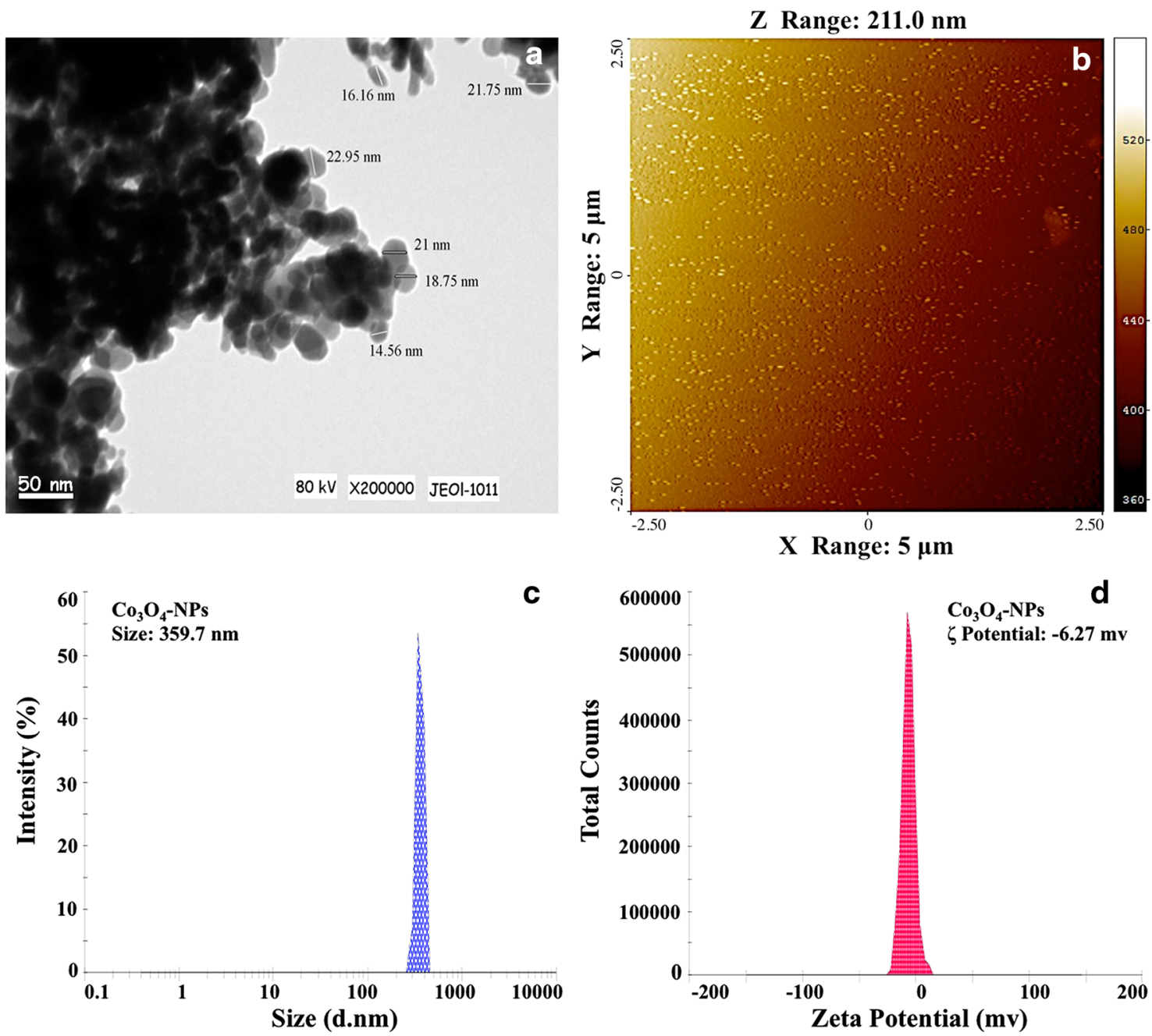

Fig. 1 TEM analysis of $\mathrm{CO}_{3} \mathrm{O}_{4}-\mathrm{NPs}(\mathbf{a})$ at $\times 200,000$ magnification. b Depicts a topography of $\mathrm{Co}_{3} \mathrm{O}_{4}-\mathrm{NPs}$ in an AFM perspective. Dynamic light scattering (DLS) and $\zeta$-potential analysis of $\mathrm{CO}_{3} \mathrm{O}_{4}$-NPs suspension in ultrapure water $(\mathbf{c}, \mathbf{d})$

might be greater for the smaller seeds of eggplant as compared to the larger sized tomato seeds, largely due to greater surface-to-volume ratio of the small-sized seeds to that of the large-sized seeds [12]. These observations corroborate well with earlier literature suggesting greater phytotoxicity of rare earth oxide NPs to the smaller seeds (rape, cabbage, radish), as compared to the larger seeds of wheat [13]. Nonetheless, our results are in agreement with some recent findings, which have also demonstrated the repression of root length by $\mathrm{CuO}$ and Ag-NPs in Arabidopsis thaliana $[3,14]$. Seed coat provides first line of defense to the seed from NPs during the germination. However, in this study we have demonstrated that seedling roots after piercing the seed coat, become the main organ to confront $\mathrm{Co}_{3} \mathrm{O}_{4}$-NPs. Therefore, the toxic symptoms were more evident in roots than in other parts of seedlings. In addition, seeds rough surface, electrostatic attraction and hydrophobic interactions contributed towards NPs adsorption on the seeds. Such adsorption may facilitate the release of ions from NPs and enhance the phytotoxicity [15].

\section{$\mathrm{Co}_{3} \mathrm{O}_{4}$-NPs uptake and translocation}

To confirm the translocation of $\mathrm{Co}_{3} \mathrm{O}_{4}-\mathrm{NPs}$, ultrathin sections of root tissues from elongation zone were evaluated by TEM (Fig. 3a-f). Root elongation zone consists of newly formed differentiated cells, which elongate at a rapid rate and exhibit enhanced cell cycle activity. $\mathrm{Co}_{3} \mathrm{O}_{4}$-NPs were observed in the cytoplasm and exterior region of confluent parenchymal cells (Fig. 3c, d). NPs were recognized as dark dots and aggregates entrapped in cell vacuoles. Our TEM data on $\mathrm{Co}_{3} \mathrm{O}_{4}$-NPs corroborate with recent studies exhibiting the translocation of $\mathrm{Ag}$ and $\mathrm{ZnO}$-NPs Triticum aestivum and Schoenoplectus 

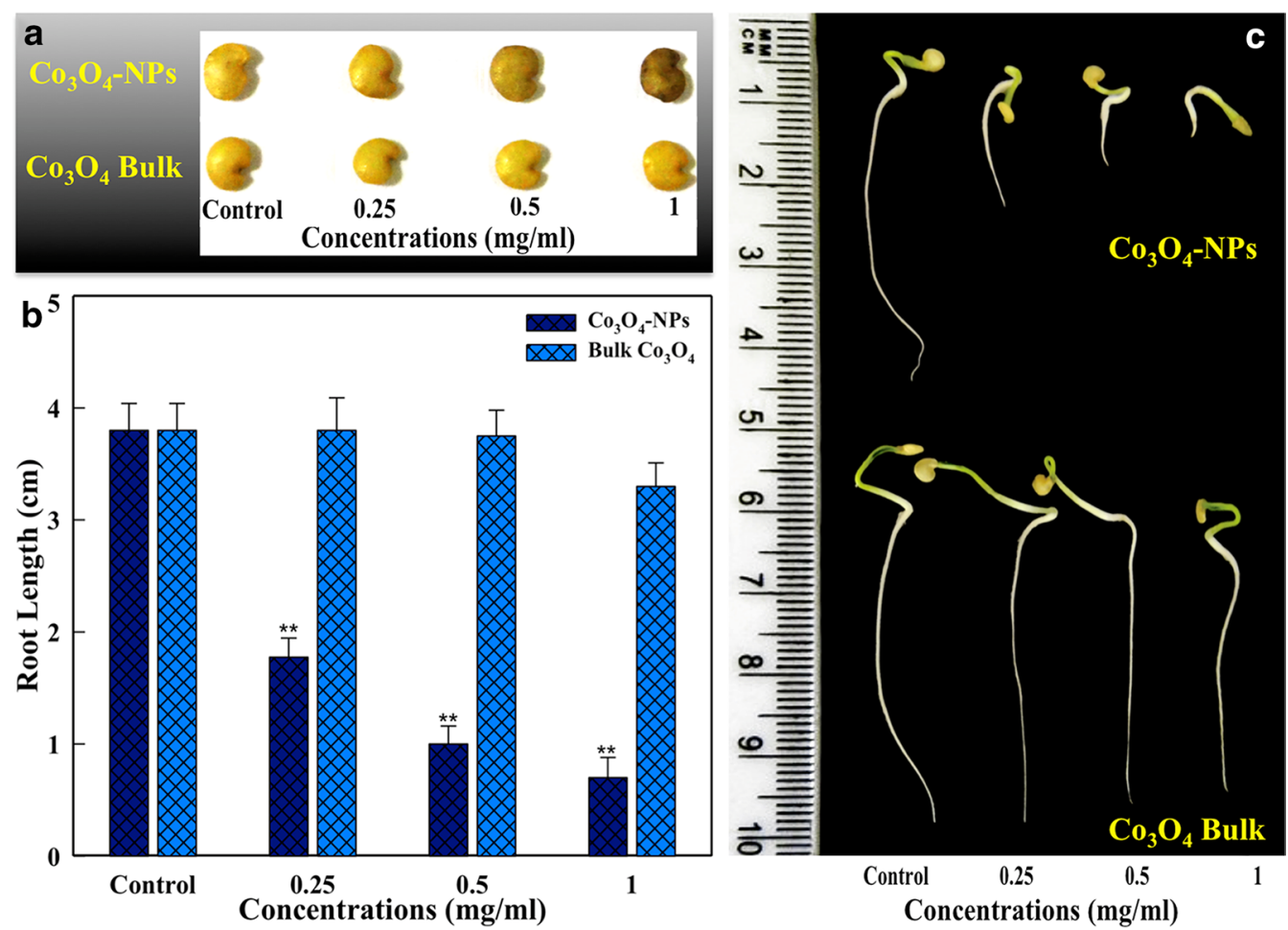

Fig. 2 a Depicts the adsorption of $\mathrm{CO}_{3} \mathrm{O}_{4}$-NPs and bulk $\mathrm{CO}_{3} \mathrm{O}_{4}$ on eggplant seeds after $2 \mathrm{~h}$ of exposure. Concentration dependent repression of average root length $(\mathbf{b})$ of eggplant ( ${ }^{* *} \mathrm{p}<0.01 \mathrm{vs}$. control). Phenotypic changes showing stunting and thickening of eggplant seedling roots after 7 days of exposure with $\mathrm{CO}_{3} \mathrm{O}_{4}-\mathrm{NPS}$, while the bulk $\mathrm{CO}_{3} \mathrm{O}_{4}$ groups exhibited normal morphology of seedling roots (c)

tabernaemontani [16, 17]. In addition, enhanced number of peroxisomes and mitochondria with degenerated cristae has also been encountered (Fig. 3c, e, f). These subcellular anomalies are found identical as observed in plants exposed to ozone [18]. Interestingly, the eukaryotic microorganism (yeast) has also demonstrated these common properties of peroxisome biogenesis as a consequence of mitochondrial dysfunction [19].

\section{Intracellular ROS production and mitochondrial dysfunction}

Qualitative evaluation of $\mathrm{Co}_{3} \mathrm{O}_{4}$-NPs treated roots exhibited a conspicuous increase in DCF fluorescence. Eggplant roots stained with fluorescent dye DCFHDA revealed a typical pattern of ROS localization as a function of $\mathrm{Co}_{3} \mathrm{O}_{4}$-NPs concentration. Compared to the untreated control, $\mathrm{Co}_{3} \mathrm{O}_{4}$-NPs at 0.25 and $0.5 \mathrm{mg} /$ $\mathrm{ml}$ showed ROS localization around apical root meristem. Subsequently, the ROS localization becomes more intense towards root elongation zone at $1.0 \mathrm{mg} /$ $\mathrm{ml}$. (Figure 4a). Protoplasts quantitatively analyzed on flow cytometry also revealed higher levels of intracellular ROS. Relative to $100 \%$ DCF fluorescence in control, $\mathrm{Co}_{3} \mathrm{O}_{4}$-NPs $(0.25,0.5$ and $1.0 \mathrm{mg} / \mathrm{ml})$ treatments resulted in 167.0, 177.4 and $157.6 \%$ greater ROS generation
(Fig. 4b, c). Our ROS data is in line with a previous study demonstrated oxidative stress in Oryza sativa treated with multiwalled carbon nanotubes [20]. It is well established that ROS rapidly interacts with distant cellular organelles and may result in DNA strand breaks, purine oxidation, protein modifications, protein-DNA cross links and mitochondrial damage [21,22].

The interplay of ROS and mitochondria has further lead us to analyze $\Delta \Psi m$ using mitochondrial specific dye Rh123. Qualitative evaluation of seedling roots from $\mathrm{Co}_{3} \mathrm{O}_{4}$-NPs treatment groups exhibited enhancement in the fluorescence intensity of Rh123 (Fig. 5a). A similar pattern of fluorescence enhancement has been observed in the protoplasts of $\mathrm{Co}_{3} \mathrm{O}_{4}$-NPs exposed groups. Flow cytometric analysis of protoplasts revealed 136.6, 144.2 and $282.4 \%$ greater fluorescence at $0.25,0.5$ and $1.0 \mathrm{mg} /$ $\mathrm{ml}$ concentrations (Fig. 5b, c). Mitochondrial dysfunction as a consequence of oxidative stress is an important factor in cell death [23, 24]. Fluorescence enhancement of Rh123 dye is related to the variation in $\Delta \Psi m$, which results as a consequence of swelling and shrinking properties of mitochondria [25]. Due to these morphological alterations, preferably by swelling, Rh123 leaks out from mitochondria to the cytoplasm [26]. Therefore, $\mathrm{Co}_{3} \mathrm{O}_{4}$-NPs mediated enhancement of Rh123 florescence 


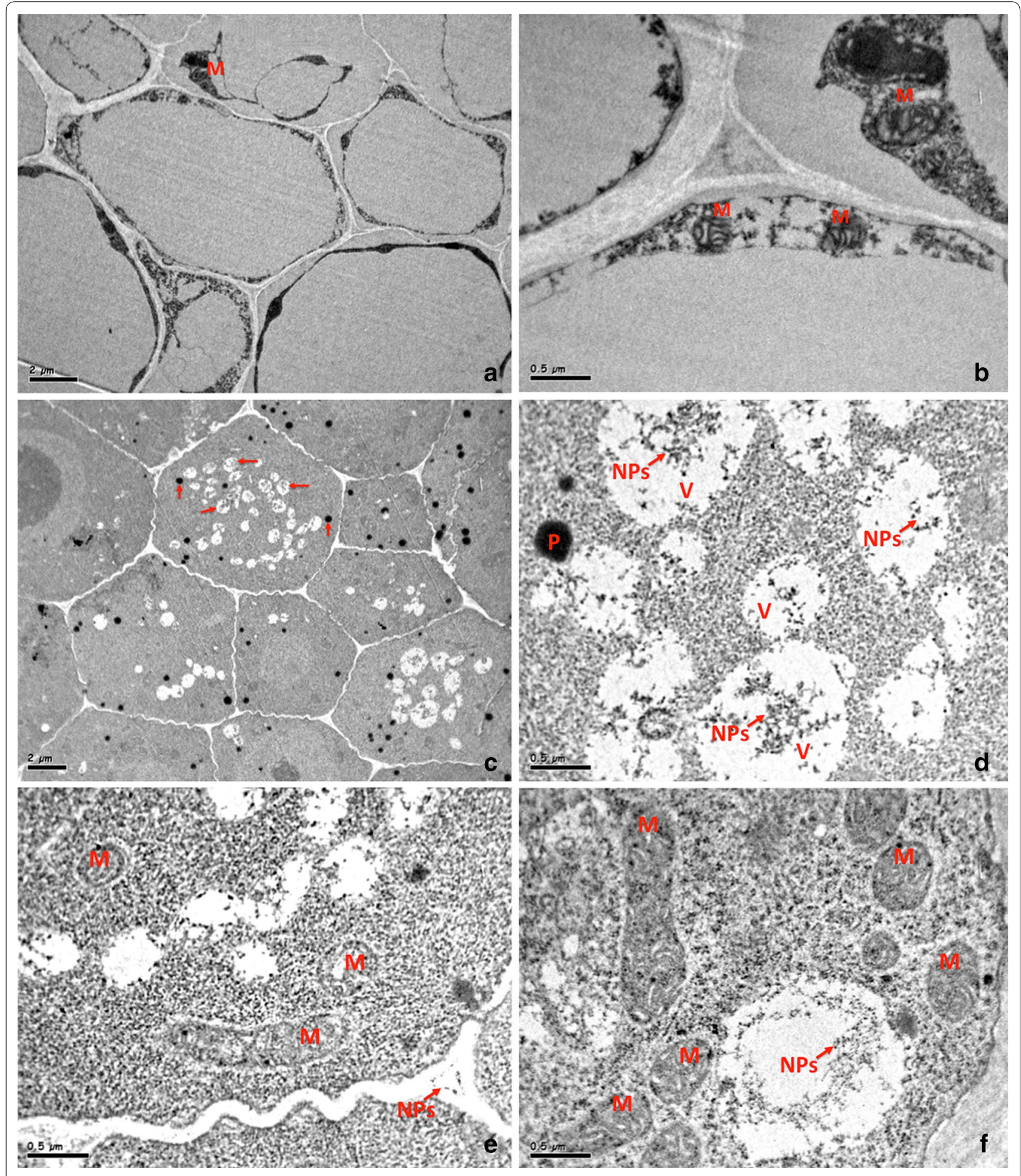

Fig. 3 TEM images of control roots showing the triangular shaped parenchymal cells and mitochondria with integrated cristae, and no appearance of peroxisomes and vacuoles $(\mathbf{a}, \mathbf{b})$. Ultrastructural images of root sections from $1 \mathrm{mg} / \mathrm{ml} \mathrm{Co}_{3} \mathrm{O}_{4}$-NPs treatment groups showing extensive vacuoles with NPs aggregates, mitochondria with degenerated cristae and abundance of peroxisomes $(\mathbf{c}, \mathbf{d}, \mathbf{f})$. The extracellular region of parenchymatic cells showing the nanoparticles aggregates (e). Vacuoles (V), mitochondria (M), peroxisomes (P), nanoparticles (NPs) 
a
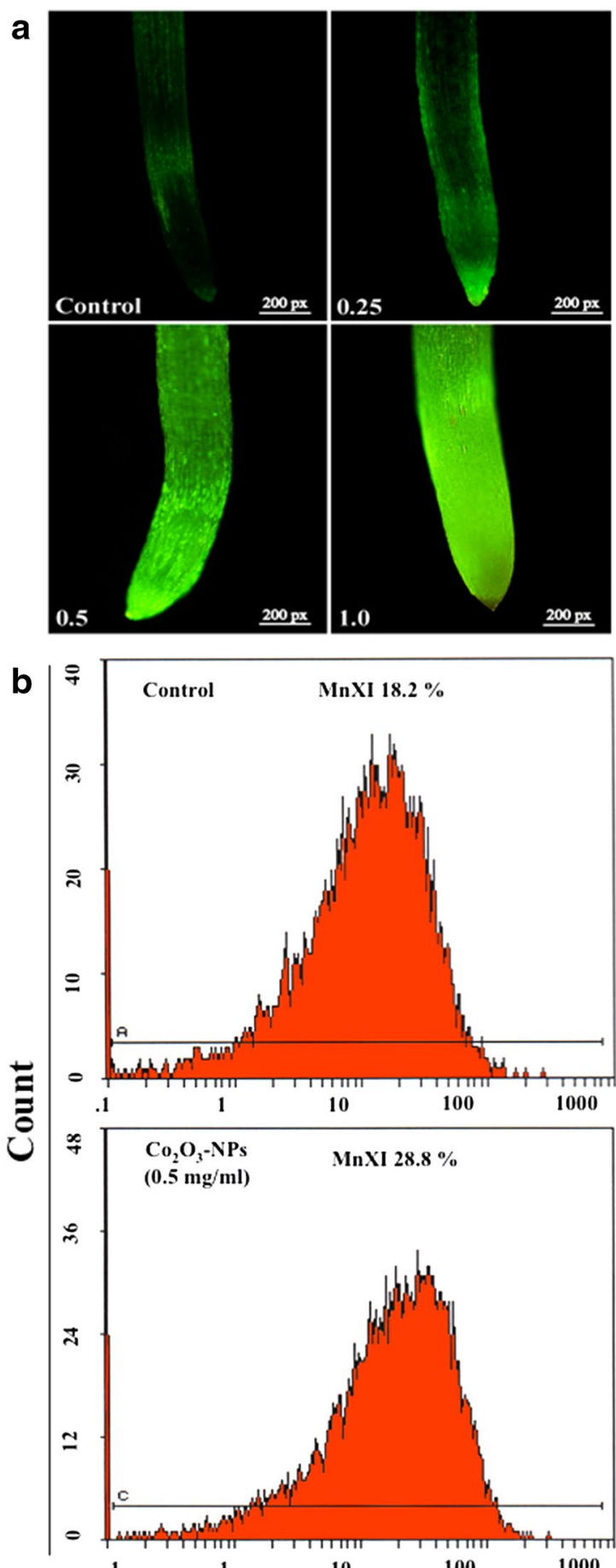
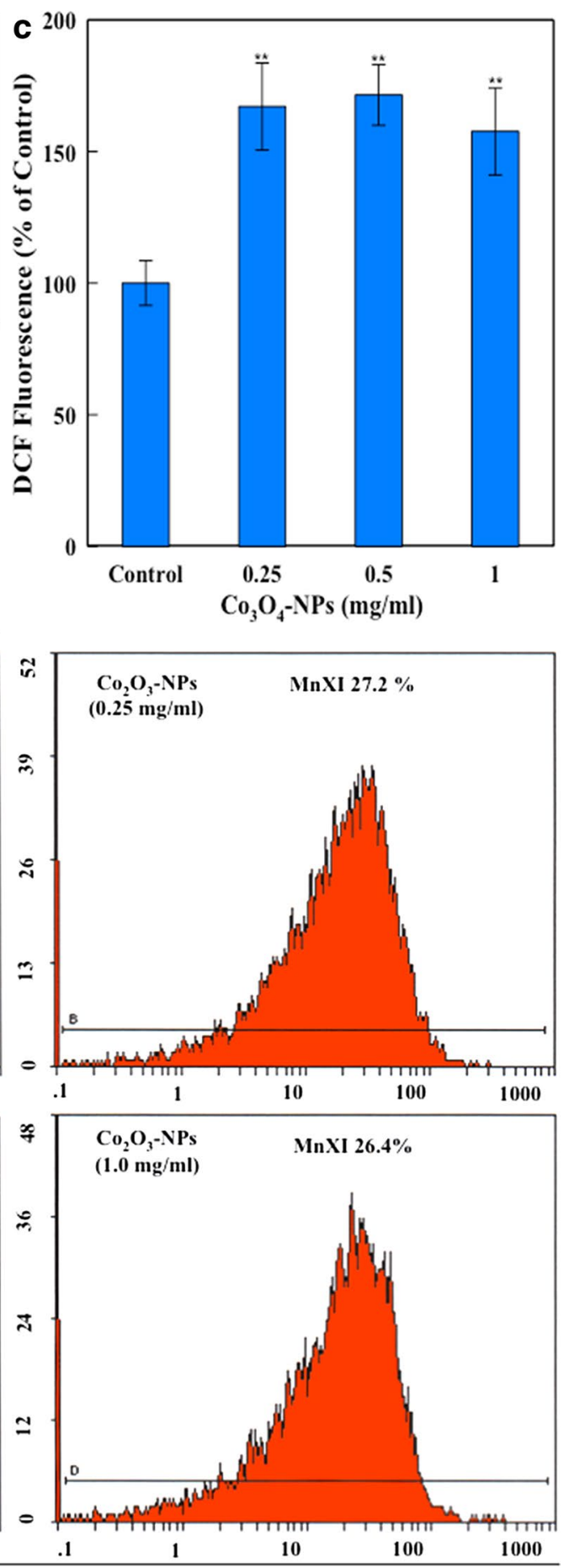

FL1 Log DCF

Fig. 4 a Depicts DCF fluorescence in eggplant seedling roots with localization of ROS in root tip, area of elongation and differentiation. Representative flow cytometric images $(\mathbf{b})$ and average DCF fluorescence (c) reaffirming intracellular ROS generation in protoplasts of $\mathrm{CO}_{3} \mathrm{O}_{4}-\mathrm{NPs}$ treated groups. $\mathrm{MnXI}=$ mean fluorescence intensity of DCF. (**p $<0.01$ vs control) 
a
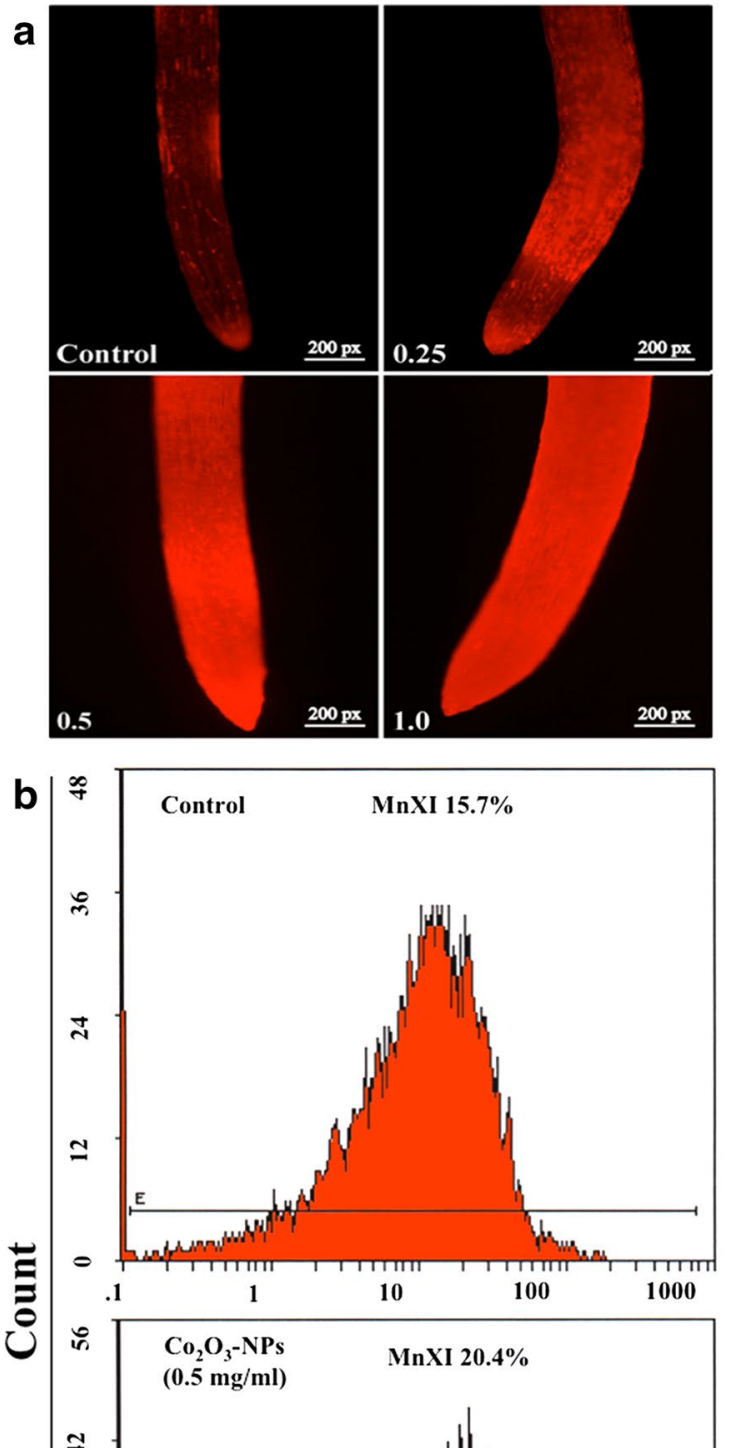

F

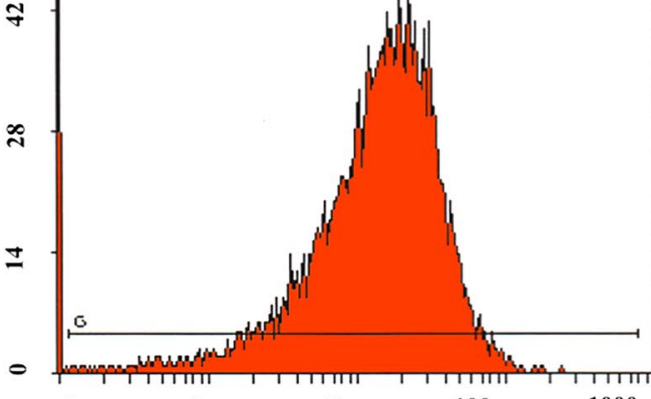

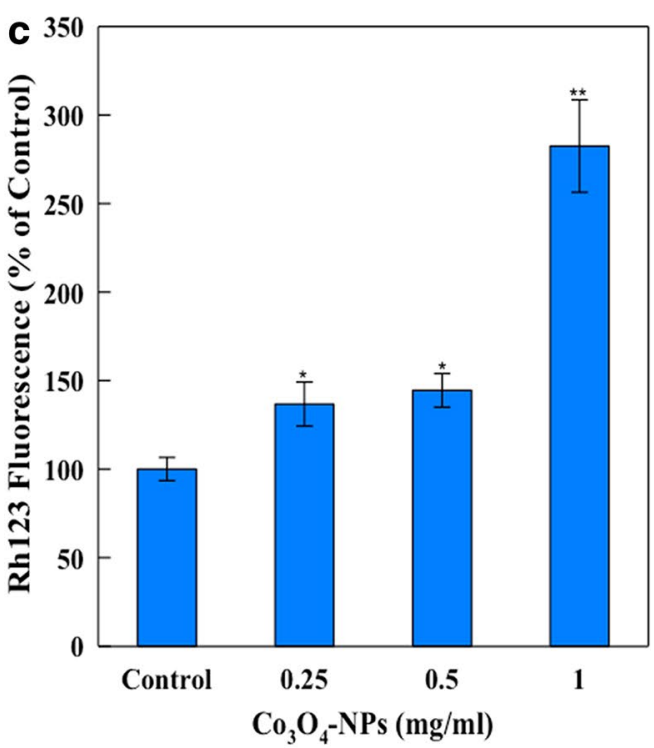
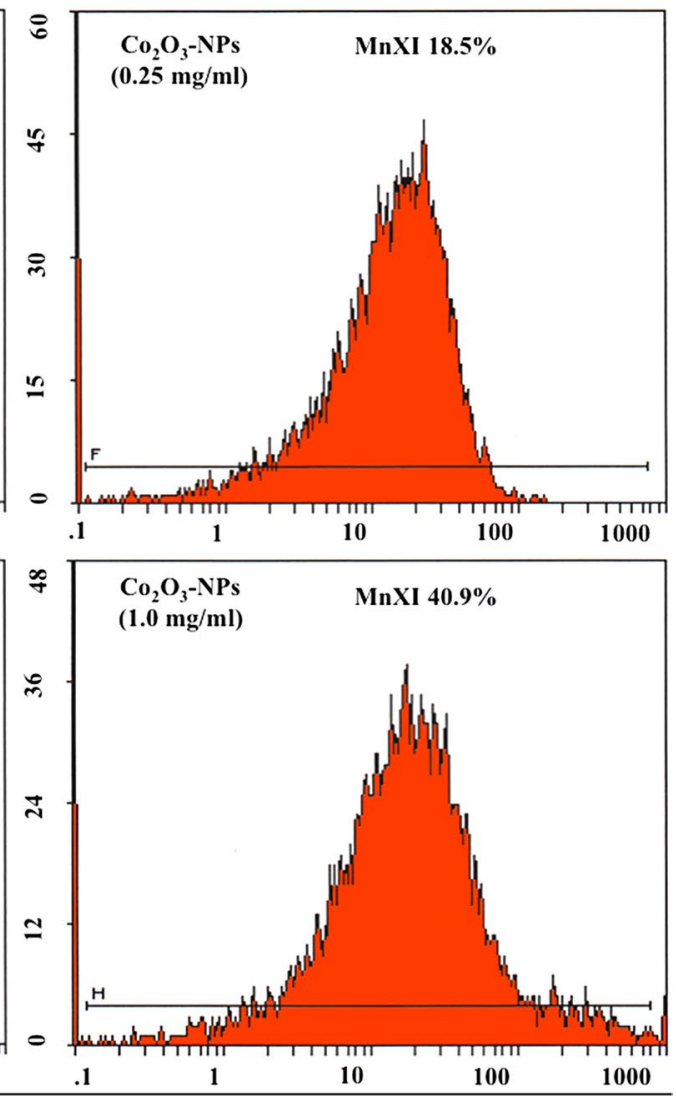

FL1 Log Rh123

Fig. 5 Qualitative analysis of Rh123 stained eggplant seedling roots showing the fluorescence enhancement upon $\mathrm{CO}_{3} \mathrm{O}_{4}-\mathrm{NPs}_{\mathrm{s}}$ exposure while control shows normal bright fluorescence of Rh123 with no diffusion of dye throughout root length (a). The representative flow cytometric images (b) and average Rh123 fluorescence (c) reaffirming mitochondrial dysfunction in protoplasts of $\mathrm{CO}_{3} \mathrm{O}_{4}$-NPs treated groups. MnXI is the fluorescence intensity of $\operatorname{Rh} 123\left({ }^{*} p<0.05,{ }^{* *} p<0.01\right.$ vs control) 
confirm mitochondrial swelling in eggplant and the leakage of dye thus causing Rh123 hyperpolarization in cytoplasm.

\section{NO and esterase analysis}

Flow cytometric analysis of $\mathrm{Co}_{3} \mathrm{O}_{4}$-NPs treated protoplasts exhibited an increase in intracellular $\mathrm{NO}$ generation. Relative to $100 \%$ fluorescence in control, protoplasts isolated from $0.25,0.5$ and $1.0 \mathrm{mg} / \mathrm{ml} \mathrm{Co}_{3} \mathrm{O}_{4}-\mathrm{NPs}$ treated cells showed 169.8, 242.5 and $178.7 \%(\mathrm{p}<0.01)$ higher fluorescence of DAF2-DA (Fig. 6a, b). Our data is in line with earlier studies, which also suggested an elevated level of NO generation in Lupinus luteus and Glycine max exposed to $\mathrm{Cd}^{++}[27,28]$. NO has been regarded as an effective inducer of cell death by interfering with mitochondria functionality and promoting imbalance between ROS generation and scavenging [28]. Furthermore, NO has been described as a small signaling molecule in plants taking part in several events throughout the life cycle, as well as in defense against biotic and abiotic stresses [29].

We further investigated the level of intracellular esterases, regarded as a prevalent biomarker to assess the viability of cells [30]. Relative to $100 \%$ fluorescence of


Fig. 6 Representative flow cytometric images showing concentration dependent change in the mean fluorescence intensity (MnXI) of fluorescence probes DAF2-DA and CFDA specific for intracellular nitric oxide (NO) (a) and esterase activity (c) in eggplant protoplasts. Histograms shown in pane/ $\mathbf{b}$ and $\mathbf{d}$ represents changes in the mean \pm SD of fluorescence of DAF2-DA and CFDA (MnXI) obtained from 10,000 protoplasts in three independent experiments $\left(^{*} p<0.05,{ }^{* *} p<0.01\right.$ vs. control) 
CFDA in control, $\mathrm{Co}_{3} \mathrm{O}_{4}$-NPs treated root cells at the concentrations of 0.5 and $1.0 \mathrm{mg} / \mathrm{ml}$ exhibited a decline by 29.7 and $45.2 \%$, respectively. However, no significant change in the esterase level has been observed at $0.25 \mathrm{mg} / \mathrm{ml}$ (Fig. 6c, d). CFDA fluoresces strongly when de-esterified to carboxyfluorescein (CF). Conversion to $\mathrm{CF}$ by cells indicates the integrity of the plasma membrane. An intact membrane prevents leakage of the polar dye into the medium and maintains cytoplasmic milieu, which is needed to support esterase activity [31]. Therefore, the suppressed esterase level in this study primarily suggests that $\mathrm{Co}_{3} \mathrm{O}_{4}$-NPs induce membrane damage in protoplasts and in mitochondria of eggplant cells.

\section{$\mathrm{Co}_{3} \mathrm{O}_{4}$-NPs induced DNA damage}

Alkaline single cell gel electrophoresis (comet assay) data showed $\mathrm{Co}_{3} \mathrm{O}_{4}$-NPs-induced single strand breaks in DNA of eggplant cells. The representative digitized image of comet tail in $\mathrm{Co}_{3} \mathrm{O}_{4}$ - $\mathrm{NPs}(1.0 \mathrm{mg} / \mathrm{ml})$ treated group clearly demonstrates the extent of broken DNA liberated from head of the comet during electrophoresis (Fig. 7 inset). However, under identical condition the control cell exhibited round boundary of nuclear head DNA. A conspicuous tail in positive control ethyl methanesulfonate (EMS $2 \mathrm{mM}$ ) confirms the proper functioning of comet setup (Fig. 7 inset). Compared to the olive tail moment (OTM) value of $1.22 \pm 0.12$ in control, the quantitative data obtained from 150 cells of $\mathrm{Co}_{3} \mathrm{O}_{4}$-NPs $(0.25,0.5$ and



Fig. 7 Inset shows the representative epi-fluorescence comet images of $\mathrm{CO}_{3} \mathrm{O}_{4}$-NPs-induced DNA damage in eggplant nuclei analyzed by alkaline single cell gel electrophoresis. Quantitative analysis of DNA damage using Comet assay IV software shows a concentration dependent single strand breaks in eggplant nuclei. Each data point represents $\pm S D$ value of three independent experiments done in duplicate comet slides. EMS; Ethyl methanesulfonate (2 mM) taken as positive control
$1.0 \mathrm{mg} / \mathrm{ml}$ ) treatment groups exhibited an increase of $2.6 \pm 0.49,3.0 \pm 0.14$ and $3.2 \pm 0.35(\mathrm{p}<0.01)$, respectively, over control (Fig. 7). The DNA damaging activity of $\mathrm{Co}_{3} \mathrm{O}_{4}$-NPs has been found to be similar to the DNA damaging effect of $\mathrm{TiO}_{2}$ and $\mathrm{ZnO}-\mathrm{NPs}$ reported in $A$. cepa [32]. Thus, the results substantiate the hypothesis that plant-NPs interaction is associated with the genotoxicity and concurs well with the earlier reports. Metal oxides as well as metals are involved in ROS formation, which can interact directly or indirectly with plant DNA to induce strand breaks [33, 34]. However, on the basis of our data we suggest that $\mathrm{Co}_{3} \mathrm{O}_{4}$-NPs may have indirectly induce DNA damage in eggplant, as evident from increase in the ROS, mitochondrial membrane damage and elevated esterase level. On the contrary, the $\mathrm{NiO}$ NPs may have directly interacted with the DNA to induce non-repairable heavy damage; as a result an increasing number of apoptotic/necrotic cells were appeared in the comet assay of tomato cells [11]. Thus, an in-depth investigation is warranted in order to ascertain the extent and nature of direct interactions of $\mathrm{Co}_{3} \mathrm{O}_{4}$-NPs using spectrofluorometric, spectrophotometric biophysical and bioinformatics tools.

\section{Flow cytometric analysis of apoptosis}

In order to assess $\mathrm{Co}_{3} \mathrm{O}_{4}$-NPs induced cell death, the apoptotic events occurred in treated eggplants cells were captured by use of a flow cytometer. The propiodium iodide (PI) stained nuclei of $\mathrm{Co}_{3} \mathrm{O}_{4}$-NPs treatment groups indicated a concentration dependent increase in apoptotic sub-G1 peak (Fig. 8a). In comparison with $24.4 \%$ of background apoptotic cells in control, $\mathrm{Co}_{3} \mathrm{O}_{4}$ NPs at $0.25,0.5$ and $1.0 \mathrm{mg} / \mathrm{ml}$ exhibited $44.4,69.8$ and $73.2 \%$ of apoptotic population (Fig. $8 \mathrm{~b}$ ). A similar mode of cell death has also been observed in our earlier report on tomato cells exposed to NiO-NPs [11]. Furthermore, our ongoing studies on cultured human cell lines with $\mathrm{Co}_{3} \mathrm{O}_{4}$-NPs have demonstrated that these NPs have the potential to induce apoptosis in the human cell lines (data unpublished). It is widely accepted that apoptotic mechanisms in plants and animals share some common components leading to conserved cellular events [35, 36]. Therefore, it is likely that eggplant root cells may activate a similar mechanism of cell death.

\section{Conclusions}

In conclusion, our study demonstrates that eggplant exposed to $\mathrm{Co}_{3} \mathrm{O}_{4}$-NPs exhibited a significant repression of root growth due to phytotoxic properties of NPs. Ultrastructural analysis suggests the subcellular localization of $\mathrm{Co}_{3} \mathrm{O}_{4}$-NPs to induce organelles damage. Fluorescence imaging and flow cytometric data supported 



FL4 Log PI



Fig. 8 Effect of $\mathrm{CO}_{3} \mathrm{O}_{4}$-NPs on cell cycle of eggplant. a Flow images exhibiting disruption of cell cycle peaks with increasing concentrations of $\mathrm{CO}_{3} \mathrm{O}_{4}$-NPs. b Individual histograms represents the mean $\pm \mathrm{SD}$ values of different phases of cell cycle 
the fact that ROS plays a crucial role in mitochondrial damage to trigger apoptosis in eggplant. Higher level of $\mathrm{NO}$ and mitochondrial membrane damage revealed that $\mathrm{Co}_{3} \mathrm{O}_{4}$-NPs trigger cell death in eggplant via mitochondrial swelling and stimulation of NO signaling pathway. Furthermore, the depletion of esterase activities in cells could serve as a useful biomarker of $\mathrm{Co}_{3} \mathrm{O}_{4}$-NPs mediated cellular stress. Presumably, the root cells exhibiting NPs induced cell death may share some similar apoptotic characters, as observed in animals. Nonetheless, a deep investigation is warranted on transcriptome analysis to investigate the possible connection between different apoptotic factors. Finally, we conclude with the remark that the current findings will provide strong background to explore NPs induced toxicity at field or farm level to determine a realistic exposure scenario for other crops.

\section{Methods}

\section{Characterization of nanoparticles}

$\mathrm{Co}_{3} \mathrm{O}_{4}$-NPs $(1 \mathrm{mg} / \mathrm{ml})$ (Cat. No. 637025, Sigma-Aldrich, St. Louis, MO, USA) were sonicated in ultrapure water for $10 \mathrm{~min}$ at $50 \mathrm{~W}$, and the solution was dropped on copper grids of the transmission electron microscope (TEM). A total of six grids of $\mathrm{Co}_{3} \mathrm{O}_{4}$-NPs were prepared and subjected to TEM analysis at $200 \mathrm{keV}$. Characterizations of $\mathrm{Co}_{3} \mathrm{O}_{4}$-NPs were further done by analyzing the surface topography of powdered $\mathrm{Co}_{3} \mathrm{O}_{4}$-NPs using atomic force microscope (AFM) (Veeco Instruments, USA) in noncontact tapping mode. The topographical images were obtained in tapping mode with a resonance frequency of $218 \mathrm{kHz}$. Characterization of $\mathrm{Co}_{3} \mathrm{O}_{4}$-NPs was further done in liquid environment by measuring the dynamic

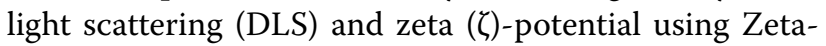
sizer 2000 (ZetaSizer-HT, Malvern, UK). Briefly, $\mathrm{Co}_{3} \mathrm{O}_{4^{-}}$ NPs stock suspension of $10 \mu \mathrm{g} / \mathrm{ml}$ was prepared in ultrapure water, sonicated for $15 \mathrm{~min}$ at $40 \mathrm{~W}$ and the

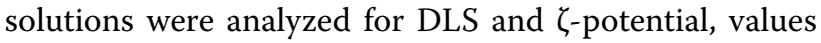
presented were the average of 10 readings.

\section{Eggplant root length retardation by $\mathrm{Co}_{3} \mathrm{O}_{4}-\mathrm{NPs}$ and bulk $\mathrm{CO}_{3} \mathrm{O}_{4}$}

To determine the phytotoxicity in Solanum melongena $\mathrm{L}$. $\mathrm{cv}$. Violetta lunga 2. (eggplant), we have selected $\mathrm{Co}_{3} \mathrm{O}_{4}$ NPs and its bulk counterpart $\mathrm{Co}_{3} \mathrm{O}_{4}$ (Cat. No. 221643, Sigma-Aldrich, St. Louis, MO, USA). Seeds of eggplant were surface sterilized in Clorox solution $(5 \% \mathrm{v} / \mathrm{v})$ for $10 \mathrm{~min}$ followed by through washing with distilled water. The exposure concentrations of $\mathrm{Co}_{3} \mathrm{O}_{4}$-NPs were selected from initial experiments based on the root elongation assay. For each set of experiment, 20 seeds were treated with $0.025,0.05,0.1,0.25,0.5$ and $1.0 \mathrm{mg} / \mathrm{ml}$ of $\mathrm{Co}_{3} \mathrm{O}_{4}-$ NPs $(<50 \mathrm{~nm})$ and bulk $\mathrm{Co}_{3} \mathrm{O}_{4}(<10 \mu \mathrm{m})$ suspensions for $2 \mathrm{~h}$ on a rotary shaker. Parallel untreated controls were run under identical conditions. After treatment, seeds were thoroughly washed with distilled water and transferred to Petri dishes containing wet filter papers. Petri dishes were kept in the growth chamber at $25 \pm 2{ }^{\circ} \mathrm{C}$ for 7 days for seed germination and growth.

\section{Uptake of $\mathrm{Co}_{3} \mathrm{O}_{4}-\mathrm{NPs}$}

Subcellular changes in eggplant root cells were analyzed by use of TEM. Root tissues from control and $\mathrm{Co}_{3} \mathrm{O}_{4}-$ NPs $(1.0 \mathrm{mg} / \mathrm{ml})$ groups were fixed in glutaraldehyde for $10 \mathrm{~min}$; followed by re-suspension of root sections in $\mathrm{OsO}_{4}(1 \%)$ for $1 \mathrm{~h}$ at $4{ }^{\circ} \mathrm{C}$. An additional incubation of $1 \mathrm{~h}$ was given for each section in $2 \%$ aqueous uranyl acetate pursued by the dehydration of sections using ascending grade of ethanol. Root sections were finally embedded in low viscosity araldite resin and ultrathin sections of $80 \mathrm{~nm}$ were made from elongation zone for TEM analysis under high vacuum $(100 \mathrm{kV})$.

\section{Flow cytometric analysis of intracellular ROS and mitochondrial dysfunction $\left(\Delta \psi_{m}\right)$}

For qualitative analysis of ROS and $\Delta \Psi m, \mathrm{Co}_{3} \mathrm{O}_{4}-\mathrm{NPs}$ treated seedling roots were stained with $2^{\prime}, 7^{\prime}$-dichlorofluorescin diacetate (DCFH-DA) $(0.25 \mu \mathrm{M})$ and $1 \mu \mathrm{g} / \mathrm{ml}$ of rhodamine 123 (Rh123) for $15 \mathrm{~min}$. Roots were washed three times with PBS, and images were captured using a fluorescence microscope (Nikon Eclipse 80i, Japan) [10, 11]. Quantitative estimation of intracellular ROS and $\Delta \Psi m$ was done in protoplasts isolated from control and $\mathrm{Co}_{3} \mathrm{O}_{4}$-NPs treated groups according to the method of Imanishi et al. [37], with slight modification [11]. In brief, 10 root tissues from each of control and treated samples were incubated in $1.5 \%$ cellulose, $0.5 \%$ pectinase (Sigma) in Galbraith buffer (45 mM MgCl, $30 \mathrm{mM}$ sodium citrate, $20 \mathrm{mM}$ MOPS, $0.1 \%(\mathrm{v} / \mathrm{v})$ Triton X-100, $\mathrm{pH}$ 7.0) for overnight in the dark at $26{ }^{\circ} \mathrm{C}$. The digested root/enzyme solution was filtered through a $100 \mu \mathrm{m}$ sieve and viable cells recovered by flotation after centrifugation in Galbraith buffer. Centrifugation and recovery steps of intact cells were repeated thrice to remove enzymes. Protoplasts from control and $\mathrm{Co}_{3} \mathrm{O}_{4}$ NPs treated groups were separately stained with DCFH$\mathrm{DA}(5 \mu \mathrm{M})$ and Rh123 $(5 \mu \mathrm{g} / \mathrm{ml})$ for $1 \mathrm{~h}$ in the dark at room temperature. Fluorescence of 10,000 protoplasts from each dye treatment was recorded on Beckman Coulter flow cytometer (Coulter Epics XL/Xl-MCL, USA) following our previously described methods $[38,39]$.

\section{Assessment of NO and esterase activity by flow cytometer}

Intracellular $\mathrm{NO}$ and esterase activities in protoplasts were measured using flow cytometry. Protoplasts isolated from $\mathrm{Co}_{3} \mathrm{O}_{4}$-NPs treated, and untreated eggplant seedling roots were washed twice with PBS and incubated with NO specific dye 4,5-diaminofluorescein 
diacetate (DAF2-DA, $5 \mu \mathrm{M}$ ) and esterase specific carboxyfluorescein diacetate (CFDA, $5 \mu \mathrm{M}$ ) for $60 \mathrm{~min}$ in the dark at room temperature. The protoplast suspensions were pelleted, followed by two successive washes with PBS at $3000 \mathrm{rpm}$ at $4{ }^{\circ} \mathrm{C}$ for $4 \mathrm{~min}$. The protoplasts were re-suspended in a final volume of $500 \mu \mathrm{l}$ of PBS and the fluorescence of DAF2-DA and CFDA was measured in 10,000 protoplasts using a flow cytometer at log scale (FL-1, $530 \mathrm{~nm})$.

\section{DNA damage analysis by alkaline comet assay}

The comet assay was performed to analyze the DNA damage in nuclei following the method described by Faisal et al. [10]. Nuclei were isolated by chopping the root tissues using a sharp scalpel blade in $1.0 \mathrm{ml}$ of Galbraith buffer $\left(45 \mathrm{mM} \mathrm{MgCl}_{2}, 30 \mathrm{mM}\right.$ sodium citrate, $20 \mathrm{mM}$ MOPS, $0.1 \%$ (v/v) Triton X-100, pH 7.0). Comet slides were prepared following our previously described method [40].

\section{Flow cytometric analysis of apoptosis in eggplant}

Apoptosis analysis in eggplant roots was done using flow cytometry following our previously described method [11]. Nuclei suspensions $(1.0 \mathrm{ml})$ from control and $\mathrm{Co}_{3} \mathrm{O}_{4}$-NPs treated groups were stained with $10 \mu \mathrm{g} / \mathrm{ml}$ of DNA intercalating fluorescent dye (propidium iodide, PI) and RNAase A ( $50 \mu \mathrm{g} / \mathrm{ml})$ solutions for $10 \mathrm{~min}$ on ice. Red fluorescence of 100,000 events of PI stained nuclei were acquired in FL4 Log channel through a $675 \mathrm{~nm}$ band-pass filter [38]. Data were analyzed excluding the cell debris, characterized by a low FSC/SSC, using Beckman Coulter flow cytometer (Coulter Epics XL/Xl-MCL, USA and System II Software, Version 3.0).

\section{Statistical analysis}

Data were expressed as mean \pm standard deviation (SD) for the values obtained from at least three independent experiments using 20 seeds/concentration. Statistical analysis was performed by one-way analysis of variance (ANOVA) followed by Dunnett's multiple comparisons test (Sigma Plot 11.0, USA). The level of statistical significance chosen was $\mathrm{p}<0.05$, unless otherwise stated.

\begin{abstract}
Authors' contributions
MF, QS both designed the study and drafted the manuscript. MF, QS both performed the seed germination, flow cytometric and DNA damage experiments. SMA, HAA performed the fluorescence microscopic studies. SD performed the physiochemical characterization of NPs. MA performed the TEM experiments. AAA, AAK contributed by reagents, materials, instrumentation and lab space. JM, SP analyzed the experimental data and contributed in discussion of experimental outcomes. All authors read and approved the final manuscript.
\end{abstract}

\section{Author details}

1 Department of Botany and Microbiology, College of Sciences, King Saud University, P.O Box 2455, Riyadh 11451, Saudi Arabia. ${ }^{2}$ A.R. Al-Jeraisy Chair for DNA Research, Zoology Department, College of Sciences, King Saud University, P.O. Box 2455, Riyadh 11451, Saudi Arabia. ${ }^{3}$ Zoology Department, College of Sciences, King Saud University, P.O Box 2455, Riyadh 11451, Saudi Arabia. ${ }^{4}$ Department of Agricultural Microbiology, Faculty of Agricultural Sciences, AMU, Aligarh 202002, India. ${ }^{5}$ Department of Biosciences and Biotechnology, Baba Ghulam Shah Badshah University, Rajouri 185131, Jammu and Kashmir, India. ${ }^{6}$ Division of Plant Pathology, Indian Agricultural Research Institute, New Delhi 110012, India.

\section{Acknowledgements}

This project was funded by the National Plan for Science, Technology and Innovation (MAARIFAH), King Abdul Aziz City for Science and Technology, Kingdom of Saudi Arabia, Award Number 12-BIO2919-02.

\section{Competing interests}

The authors declare that they have no competing interests.

Received: 15 September 2015 Accepted: 10 March 2016

Published online: 18 March 2016

\section{References}

1. Navarro E, Baun A, Behra R, Hartmann NB, Filser J, Miao AJ, Quigg A, Santschi PH, Sigg L. Environmental behavior and ecotoxicity of engineered nanoparticles to algae, plants, and fungi. Ecotoxicology. 2008;17:372-86.

2. Liu HH, Cohen Y. Multimedia environmental distribution of engineered nano-materials. Environ Sci Technol. 2014;48:3281-92.

3. Thuesombat $P$, Hannongbua S, Akasit S, Chadchawan S. Effect of silver nanoparticles on rice (Oryza sativa L. cv. KDML 105) seed germination and seedling growth. Ecotoxicol Environ Saf. 2014;104:302-9.

4. Trujillo-Reyes J, Majumdar S, Botez CE, Peralta-Videa JR, Gardea-Torresdey $J$ L. Exposure studies of core-shell Fe/Fe(3)O(4) and Cu/CuO NPs to lettuce (Lactuca sativa) plants: are they a potential physiological and nutritional hazard? J Hazard Mater. 2014;267:255-63.

5. Wang C, Liu H, Chen J, Tian Y, Shi J, Li D, Guo C, Ma Q. Carboxylated multiwalled carbon nanotubes aggravated biochemical and subcellular damages in leaves of broad bean (Vicia faba L.) seedlings under combined stress of lead and cadmium. J Hazard Mater. 2014;274:404-12.

6. Pakrashi S, Jain N, Dalai S, Jayakumar J, Chandrasekaran PT, Raichur AM, Chandrasekaran N, Mukherjee A. In vivo genotoxicity assessment of titanium dioxide nanoparticles by Allium cepa root tip assay at high exposure concentrations. PLoS One. 2014;9:e87789.

7. Liu X, Qiu G, Li X. Shape-controlled synthesis and properties of uniform spinel cobalt oxide nanotubes. Nanotechnology. 2005;16:3035-40.

8. Fu L, Liu Z, Liu Y, Han B, Hu P, Cao L, Zhu D. Beaded cobalt oxide beaded cobalt oxide nanoparticles along carbon nanotubes: towards more highly integrated electronic devices. Adv Mater. 2005;17:217-21.

9. Ghodake G, Seo YD, Lee DS. Hazardous phytotoxic nature of cobalt and zinc oxide nanoparticles assessed using Allium cepa. J Hazard Mater. 2010;186:952-9555.

10. Berne BJ, Pecora R. Dynamic light scattering: with applications to chemistry, biology and physics. Mineola: Dover Publications; 2000.

11. Faisal M, Saquib Q, Alatar AA, Al-Khedhairy AA, Hegazy AK, Musarrat J. Phytotoxic hazards of NiO-nanoparticles in tomato: a study on mechanism of cell death. J Hazard Mater. 2013;250-251:318-32.

12. Lin D, Xing B. Root uptake and phytotoxicity of $\mathrm{ZnO}$ nanoparticles. Environ Sci Technol. 2008;42:5580-5.

13. Ma Y, Kuang L, He X, Bai W, Ding Y, Zhang Z, Zhao Y, Chai Z. Effects of rare earth oxide nanoparticles on root elongation of plants. Chemosphere. 2010;78:273-9.

14. Nair PM, Chung IM. Impact of copper oxide nanoparticles exposure on Arabidopsis thaliana growth, root system development, root lignificaion, and molecular level changes. Environ Sci Pollut Res Int. 2014;21:12709-127022.

15. Atha DH, Wang H, Petersen EJ, Cleveland D, Holbrook RD, Jaruga $P$, Dizdaroglu M, Xing B, Nelson BC. Copper oxide nanoparticle mediated DNA damage in terrestrial plant models. Environ Sci Technol. 2012;46:1819-27

16. Vannini C, Domingo G, Onelli E, De Mattia F, Bruni I, Marsoni M, Bracale M. Phytotoxic and genotoxic effects of silver nanoparticles exposure 
on germinating wheat seedlings. J Plant Physiol. 2014;171:1142-8 doi:10.1016/j.jplph.2014.05.002.

17. Zhang D, Hua T, Xiao F, Chen C, Gersberg RM, Liu Y, Stuckey D, Ng WJ, Tan SK. Phytotoxicity and bioaccumulation of $\mathrm{ZnO}$ nanoparticles in Schoenoplectus tabernaemontani. Chemosphere. 2014;120C:211-9.

18. Oksanen E, Häikiö E, Sober J, Karnosky DF. Ozone-induced $\mathrm{H}_{2} \mathrm{O}_{2}$ accumulation in field-grown aspen and birch is linked to foliar ultrastructure and peroxisomal activity. New Phytol. 2003;161:791-9.

19. Chelstowska A, Butow RA. RTG genes in yeast that function in communication between mitochondria and the nucleus are also required for expression of genes encoding peroxisomal proteins. J Biol Chem. 1995;270:18141-6.

20. Tan X, Lin C, Fugetsu B. Studies on toxicity of multi-walled carbon nanotubes on suspension rice cells. Carbon. 2009;47:3479-87.

21. Beckman KB, Ames BN. Oxidative decay of DNA. J Biol Chem. 1997;272:19633-6.

22. Marine A, Krager KJ, Aykin-Burns N, Macmillan-Crow LA. Peroxynitrite induced mitochondrial biogenesis following MnSOD knockdown in normal rat kidney (NRK) cells. Redox Biol. 2014;23:348-57.

23. Indo HP, Davidson M, Yen HC, Suenaga S, Tomita K, Nishii T, Higuchi M, Koga Y, Ozawa T, Majima HJ. Evidence of ROS generation by mitochondria in cells with impaired electron transport chain and mitochondrial DNA damage. Mitochondrion. 2007;7:106-18.

24. Yao N, Eisfelder BJ, Marvin J, Greenberg JT. The mitochondrion-an organelle commonly involved in programmed cell death in Arabidopsis thaliana. Plant J. 2004;40:596-610.

25. Petit PX. Flow cytometric analysis of rhodamine-123 fluorescence during modulation of the membrane potential in plant mitochondria. Plant Physiol. 1992;98:279-86.

26. Ouédraogo G, Morlière P, Santus R. Miranda Castell JV. Damage to mitochondria of cultured human skin fibroblasts photosensitized by fluoroquinolones. Photochem Photobiol. 2000;58:20-5.

27. Arasimowicz-Jelonek M, Floryszak-Wieczorek J, Deckert J, RucińskaSobkowiak R, Gzyl J, Pawlak-Sprada S, Abramowski D, Jelonek T, Gwóźdź EA. Nitric oxide implication in cadmium-induced programmed cell death in roots and signaling response of yellow lupine plants. Plant Physiol Biochem. 2012;58:124-34.

28. Kopyra M, Stachon-Wilk M, Gwozdz EA. Effects of exogenous nitric oxide on the antioxidant capacity of cadmium-treated soybean cell suspension. Acta Physiol Plant. 2006;28:525-36.
29. Zottini M, Costa A, De Michele R, Schiavo FL. Role of nitric oxide in programmed cell death. In: Hayat S, Mori M, Pichtel J, Ahmad A, editors. Nitric oxide in plant physiology. Weinheim: Wiley-VCH Verlag GmbH \& Co. KGaA; 2010. p. 77-87.

30. Amano T, Hirsawa Ki, O'Donohue MJ, Shioi Y. A versatile assay for the accurate, time-resolved determination of cellular viability. Anal Biochem. 2003;314:1-7

31. Gorokhova E, Mattsson L, Sundström AM. A comparison of TO-PRO-1 iodide and 5-CFDA-AM staining methods for assessing viability of planktonic algae with epifluorescence microscopy. J Microbiol Methods. 2012:89:216-21.

32. Demir E, Kaya N, Kaya B. Genotoxic effects of zinc oxide and titanium dioxide nanoparticles on root meristem cells of Allium cepa by comet assay. Turk J Biol. 2014;38:31-9.

33. Zhang $\mathrm{H}$, Jiang $Y, \mathrm{He} Z$, Ma M. Cadmium accumulation and oxidative burst in garlic (Allium sativum). J Plant Physiol. 2005;162:977-84.

34. Kumari M, Mukherjee A, Chandrasekaran N. Genotoxicity of silver nanoparticles in Allium cepa. Sci Total Environ. 2009;407:5243-6.

35. Del Pozo O, Lam E. Caspases and programmed cell death in the hypersensitive response of plants to pathogens. Curr Biol. 1998;88:1129-32.

36. Mlejnek P, Prochazka S. Activation of caspase-like proteases and induction of apoptosis by isopentenyladenosine in tobacco BY-2 cells. Planta. 2002;215:158-66.

37. Imanishi S, Momose J, Hiura I. Isolation and culture of Lycopersicon esculentum root protoplasts. Plant Tissue Cult Lett. 1985;2:25-6.

38. Saquib Q, Al-Khedhairy AA, Siddiqui MA, Abou-Tarboush FM, Azam A, Musarrat J. Titanium dioxide nanoparticles induced cytotoxicity, oxidative stress and DNA damage in human amnion epithelial (WISH) cells. Toxicol In Vitro. 2012;26:351-61.

39. Saquib Q, Musarrat J, Siddiqui MA, Dutta S, Dasgupta S, Giesy JP. Al-Khedhairy AA Cytotoxic and necrotic responses in human amniotic epithelial (WISH) cells exposed to organophosphate insecticide phorate. Mutat Res. 2012;744:125-34

40. Saquib Q, Al-Khedhairy AA, Al-Arifi S, Dhawan A, Musarrat J. Assessment of methyl thiophanate-Cu (II) induced DNA damage in human lymphocytes. Toxicol In Vitro. 2009;23:848-54.

\section{Submit your next manuscript to BioMed Central and we will help you at every step:}

- We accept pre-submission inquiries

- Our selector tool helps you to find the most relevant journal

- We provide round the clock customer support

- Convenient online submission

- Thorough peer review

- Inclusion in PubMed and all major indexing services

- Maximum visibility for your research

Submit your manuscript at www.biomedcentral.com/submit
() Biomed Central 